\title{
A case of herpes zoster associated encephalitis with rapid response to acyclovir
}

\author{
J.S. Cheesbrough ${ }^{1}$, R.G. Finch ${ }^{1}$ and M.J. Ward ${ }^{2}$ \\ Departments of ${ }^{\prime}$ Microbial Disease and ${ }^{2}$ General Medicine, City Hospital, Nottingham, NG5 IPB, UK.
}

\begin{abstract}
Summary: A case of herpes zoster encephalitis which responded very rapidly to acyclovir is presented. The differential serum: cerebrospinal fluid antibody response was followed and its value in making the diagnosis is discussed. The penetration of acyclovir into the cerebrospinal fluid was measured, and found to be in agreement with predicted values.
\end{abstract}

\section{Introduction}

Herpes zoster is common in the immunosuppressed host and may undergo dissemination. Neurological complications are well recognized but encephalopathy is rare (Jemsek et al., 1983). There have been no controlled studies reporting the response of herpes zoster associated encephalitis (HZAE) to anti-viral agents; the response to vidarabine has been variable (Jemsek et al., 1983). We report a patient who had a rapid response to acyclovir.

\section{Case report}

A 30 year old woman was admitted in December 1982 with a $48 \mathrm{~h}$ history of chest pain associated with increasing somnolence and confusion. There was no history of headache, vomiting or seizures. In June 1981 she received a renal allograft having been on dialysis for $4 \mathrm{y}$ for chronic glomerulonephritis. Despite oral azathioprine $100 \mathrm{mg} / \mathrm{d}$ and once weekly intramuscular methyl prednisolone $100 \mathrm{mg}$ she developed chronic rejection with a mean creatinine of $356 \mathrm{mmol} / \mathrm{l}$ for the preceding three months.

On admission she was febrile and had a typical zoster rash in the right $\mathrm{T} 2$ dermatome with no cutaneous dissemination. She was barely responsive to commands with a Glasgow coma scale (GCS) score of ten (Teasdale \& Jennett, 1974). Four hours later she responded slowly but appropriately to simple questions, yet by twelve hours she was obtunded with dysconjugate gaze, GCS score of four. There was no meningismus or other neurological sign.

Investigations on admission revealed a

J.S. Cheesbrough, M.R.C.P.; R.G. Finch, M.R.C.P., M.R.C.Path.; M.J. Ward, M.R.C.P.

Accepted: 22 December 1983 haemoglobin of $9.5 \mathrm{~g} / \mathrm{dl}$ and a white cell count of $9.2 \times 10^{9} / 1$ with a normal differential. The plasma sodium was $139 \mathrm{mmol} / \mathrm{l}$, potassium $4.9 \mathrm{mmol} / \mathrm{l}$, urea $29.1 \mathrm{mmol} / \mathrm{l}$, creatinine $632 \mu \mathrm{mol} / 1$ and bicarbonate $9 \mathrm{mmol} / \mathrm{l}$. Liver function tests were normal except for an elevated glutamic pyruvate transaminase of 41 international units/l. She was acidotic with an arterial $\mathrm{pH}$ of 7.04 , base excess $-22, \mathrm{PaO}_{2} / \mathrm{PaCO}_{2} 14.5 \mathrm{kPa}$ and a $\mathrm{PaCO}_{2}$ of $4.30 \mathrm{kPa}$. The chest radiograph was normal and a heat computed tomography (CT) scan showed symmetrical cerebral oedema with no focal abnormalities. A urine drug screen revealed no significant finding. The cerebrospinal fluid (CSF) was examined on three occasions (Table I). Varicella-zoster virus was isolated from the skin vesicles but not the CSF.

Treatment was initiated with intravenous hydrocortisone and bicarbonate. The following day because of deepening coma intravenous acyclovir was commenced with a single loading dose of $10 \mathrm{mg} / \mathrm{kg}$, followed by $5 \mathrm{mg} / \mathrm{kg} / \mathrm{d}$ for ten days. Improvement by $24 \mathrm{~h}$ was dramatic, with a GCS score of 14 , and after $48 \mathrm{~h}$ she was fully recovered.

\section{Discussion}

Encephalitis occurs in up to $5 \%$ of patients hospitalized with herpes zoster, usually complicating disseminated disease (Marzur \& Dolin, 1978). The clinical picture is variable and non-specific, with mild confusion, hallucinations, and stupor predominating. Progression to coma is unusual, and death rare. Although coma is usually brief (1-4 days) complete mental recovery is often delayed particularly in the immunosuppressed patient in whom the mean duration of neurological symptoms is 22 days. The CSF 
Table I Results of serial CSF samples including specific antibody index and acyclovir penetration.

\begin{tabular}{|c|c|c|c|}
\hline Day of illness & 2 & 6 & 11 \\
\hline pressure $/ \mathrm{cm}$ of $\mathrm{CSF}$ & 35 & 14 & 16 \\
\hline red blood cells $/ \mathrm{mm}^{3}$ & 175 & 105 & 250 \\
\hline polymorphs $/ \mathrm{mm}^{3}$ & 1 & 0 & 0 \\
\hline lymphocytes $/ \mathrm{mm}^{3}$ & 3 & 0 & 0 \\
\hline $\mathrm{CSF} /$ plasma glucose $(\mathrm{mmol} / \mathrm{l})$ & $4.7 / 5.9$ & $2.8 / 3.8$ & $4.4 / 6.0$ \\
\hline total protein $(\mathrm{g} / \mathrm{l})$ & 0.5 & 0.4 & 0.6 \\
\hline $\mathrm{CSF} /$ serum albumin $(\mathrm{g} / \mathrm{l})$ & $0.31 / 27$ & $0.21 / 28$ & $0.19 / 31$ \\
\hline 'CSF/serum V-Z titre & $16 / 4096$ & $32 / 8192$ & $64 / 8192$ \\
\hline${ }^{2}$ Antibody index & 0.34 & 0.52 & 1.27 \\
\hline $\mathrm{CSF} /$ plasma acyclovir $\mu \mathrm{mol} / \mathrm{l}$ & not done & $0.06 / 0.14$ & $4.16 / 19.7$ \\
\hline CSF/plasma acyclovir (\%) & & 43 & 21 \\
\hline
\end{tabular}

${ }^{1}$ IgG antibody against $\mathrm{V}-\mathrm{Z}$ virus was determined by immunofluoresence and is expressed as reciprocal titre. IgM was not $\stackrel{6}{3}$ detected in the CSF and is excluded from result.

${ }^{2}$ Antibody index $=$ CSF titre/serum titre $\times$ serum albumin/CSF albumin. $\quad$ V-Z = varicella-zoster.

may be normal but a mild lymphocytic pleocytosis is more common with an elevated protein and a normal glucose. Support for the diagnosis can be sought serologically. The presence of antibody in the CSF detected by indirect immunofluoresence has been strongly associated with encephalitis and is rarely found in patients lacking neurological involvement (Gershon et al., 1980). In an attempt to distinguish local antibody production within the central nervous system (CNS) from that due to diffusion across the blood/CSF barrier an index has been described, (Klapper et al., 1981). In herpes simplex encephalitis a value above 1.9 is diagnostic. The maximum value in our patient was 1.27 . This suggests a degree of local antibody production which, although non-diagnostic by herpes simplex encephalitis criteria has yet to bc evaluated in herpes zoster infections.

The simultaneous plasma and CSF acyclovir levels show $43 \%$ penetration in the second sample taken $22 \mathrm{~h}$ after infusion and $21 \%$ in the final sample collected $1 \mathrm{~h}$ post infusion. The only other published report which

\section{References}

BLUM, R., LIAO, S. \& DE MIRANDA, P. (1982). Overview of acyclovir pharmacokinetic disposition in adults and children. Acyclovir Symposium. American Journal of Medicine. 73, 186.

GERSHON, A., STEINBERG, S., GREENBERG, S. \& TABER, L. (1980). Varicella-zoster-associated encephalitis: detection of specific antibody in cerebrospinal fluid. Journal of Clinical Microbiology, 12, 764.

JEMSEK, J., GREENBERG, S., TABER, L., HARVEY, D., GERSHON, A. \& COUCH, R. (1983). Herpes zoster associated encephalitis: clinicopathological report of 12 used predicted plasma levels indicated approximately $50 \%$ penetration (Blum et al., 1982).

The administration of corticosteroids and the correction of the acidosis may have contributed to her $\mathbb{D}$ improvement. However the clinical prodrome, abnormal CSF and CT scan with the apparent local production of specific antibody in the CSF all suppog the diagnosis of HZAE rather than a metabolie encephalopathy. Whether HZAE is due to direct vira invasion of the CNS, or a related immune phen omenon, remains uncertain. The rapid recovery that accompanied acyclovir suggests that direct viral invasion of the CNS was the cause of HZAE in this case.

\section{Acknowledgements}

We thank Dr R. Burden for allowing us to report his patient, and Professor M. Longson, Dr D. Craddock-Watson, and Dr S. Pugh for assistance with the viral serology and Dr D. Brigden at Wellcome Research Laboratories for performing the acyclovir assays.

cases and a review of the literature. Medical (Baltimore), $62,81$.

KLAPPER, P., LAING, I. \& LONGSON, M. (1981). Rapid noninvasive diagnosis of herpes encephalitis. Lancet, ii, 607. \& MAZUR, M. \& DOLIN, R. (1978). Herpes zoster at the N.I.H. N A twenty year experience. American Journal of Medicine, 65, 38.

TEASDALE, G. \& JENNETT, B. (1974). Assessment of coma and impaired consciousness. A practical scale. Lancet, ii, $\bullet$ 81. 